\title{
A Relationship between Information Technology Implementation and Acquisition of Competitive Advantages in Banking in Croatia
}

Denis Hrestak

APIS IT d.o.o., Croatia

\section{Abstract}

Strong development of information technology corresponds to a growing corporate investment into this segment, especially in the field of financial services and telecommunications. This work aims to investigate whether these investments make sense, and do they contribute to the company success. This paper presents the results of qualitative research based on a field research and quantitative econometric analysis of the banking sector's statistical data in the Republic of Croatia in order to determine relationship between information technology and electronic business implementation, and achievement of competitive advantage in the banking sector, operational costs reduction and business efficiency increase. In the theoretical part, this paper describes the role of information technology in business, development and strategic role of e-business, e-business models, and especially important, the business aspects of electronic commerce in the banking sector. Conclusion shows that there is a strong positive linear relationship between the application of ICT and achievement of a competitive advantage in the banking sector. Also, the cost per executed transaction is reduced, and there is a strong positive correlation between investments in e-business and business performance.

Keywords: ICT, technology, banking, Croatia, investment, research JEL classification: $\mathrm{O330}$

\section{Introduction}

In today's world of increased globalization of markets and the economic regionalization, business cannot be imagined without the use of modern information technology. Development of the information and communication technology has large impact on business processes and efficiency. It enables simple and fast communication, almost instantaneously transfer of large amounts of data over long distances, easily publish and update documents and their continued global availability, digital delivery of goods and services, direct payment via the Internet. All these elements represent a new form of business, so-called e-business. Electronic commerce can be viewed from several perspectives. From the aspect of communication it is electronic delivery of information, products and services and electronic payment using a computer and other communications networks. From the business point of view it is the application of technology to automate business transactions and business itself. From the standpoint of service it is a tool that allows you to reduce operating costs while increasing the quality and speed of service delivery. The role of information technology in business strategy and business 
objectives in the banking sector is becoming more and more important over time, and there is a significant impact on overall operations.

The aim of the research is to establish a relationship between information technology and e-business with the acquisition of competitive advantages of doing business in the banking sector.

Because of the conservative nature of banks' operations and the confidentiality of their data, it is difficult to gather adequate information on which can be carried out relevant research. Also, the literature in this area is very poor, so we can say that this work is the first major study of the impact of investment and use of information technology on business performance in the banks.

In the process of researching and writing this paper many books and articles were providing a great deal of help, such as: Alawneh, A. et al. (2009), Auta, E. M. (2010), Coltman, T. (2007), Devaraj, S. et al. (2002), Joseph, M. et al. (2005), Malhotra, P. et al. (2009), Nel, F. L. (2008) and Ryan, R. et al. (2010).

\section{Methodology}

Data analysis was conducted by econometric test models. For the production of the model I have used the following programs: Eviews, PHStat2, STATISTICA, Wolfram Mathematica and Excel. All data used in this analysis relate to the business entity Zagrebacka Banka Itd and are collected from public databases (Bulletin of the Croatian National Bank and annual reports of Zagrebacka banka) or are provided by Zagrebacka banka.

In the quantitative analysis econometric methodology and all appropriate tests have been used. The model is estimated by the method of simple linear regression and evaluates parameters by the least squares method. The method is chosen as the most effective given the nature of the data. The data are macroeconomic in character, observed at the level of the year so that the standard properties are to be expected in this model, since the data is aggregated. Additional tests have been made that confirm or reject the hypothesis of persistence models: Jarque-Bera test, Durbin-Watson test, White's test, SIC and Akaike criteria.

\section{Results}

Thus, the hypothesis that we will try to confirm or deny is: "The application of information technology plays an important role in achieving a competitive advantage in the banking sector."

Two variables that are visible from the hypothesis are: "the application of information technology" and "achieving a competitive advantage in the banking sector". Intuitively and empirically, before defining the model, we can say that the dependent variable is "achieving a competitive advantage in the banking sector", and an independent "the application of information technology." Empirically speaking, investing in IT, which accelerate business processes, should generate a better competitive position.

Due to economic crisis in Croatia, starting to feel more intensely in 2009., and continues to this day, we observe a period limited to years 2001-2010. 2010. is included in order to have a ten-year period, and, because of earlier investment planning, it is not influenced by austerity measures.

The first variable "the application of information technology" was defined as follows: given that information technology can be divided into two groups: hardware and software a series of data and variables is created by collecting data from the two groups which are then conjoined on the yearly basis (Table 1). 
Table 1

Zagrebacka banka Itd: Investment in IT over the Period 2001-2010 (in Millions HRK)

\begin{tabular}{lrrrrrrrrrr}
\hline Year & $\mathbf{2 0 0 1}$ & $\mathbf{2 0 0 2}$ & $\mathbf{2 0 0 3}$ & $\mathbf{2 0 0 4}$ & $\mathbf{2 0 0 5}$ & $\mathbf{2 0 0 6}$ & $\mathbf{2 0 0 7}$ & $\mathbf{2 0 0 8}$ & $\mathbf{2 0 0 9}$ & $\mathbf{2 0 1 0}$ \\
\hline Investment & 260,10 & 253,70 & 233,72 & 247,80 & 244,18 & 201,30 & 214,18 & 221,50 & 229,65 & 231,44 \\
\hline
\end{tabular}

Source: Author, Data Source: Zagrebačka banka (2011), "Godišnja izvješća 2001-2010", available

at:

http://www.zaba.hr/home/wps/wcm/connect/zaba_hr/zabapublic/odnosi_s_investitorima/fi nancijski+izvjestaji (accessed June $5^{\text {th }} 2015$ )

The second variable "achieving a competitive advantage in the banking sector" was defined as follows: achieving competitive advantage is a term that, in the contemporary theory of management and marketing, is most associated with concepts such as market leader, market challenger and market followers. That way it defines the greater competitive advantage through market share. In the banking sector, the indicator of the competitive advantage of the bank is "share of individual bank in the assets of the entire banking sector" (Table 2).

Table 2

The Share of Assets of the Zagrebacka banka Itd in the Total Assets of the Banking Sector over the Period 2001-2010

\begin{tabular}{lllllllllll}
\hline Year & 2001 & 2002 & 2003 & 2004 & 2005 & 2006 & 2007 & 2008 & 2009 & 2010 \\
\hline Share(\%) & 27,71 & 26,45 & 24,21 & 25,07 & 24,36 & 23,03 & 23,15 & 23,71 & 24,10 & 24,20 \\
\hline
\end{tabular}

Source: Author, Data Source: Hrvatska narodna banka (Croatian national bank), Bilteni, Hrvatska narodna banka, available at: http://www.hnb.hr/supervizija/hsupervizija.htm (accessed June $5^{\text {th }}$ 2015)

Two variables that are visible from the hypothesis are: "the application of information technology" and "achieving a competitive advantage in the banking sector". Intuitively and empirically, before defining the model, we can say that the dependent variable is "achieving a competitive advantage in the banking sector", and an independent "the application of information technology." Empirically speaking, investing in IT, which accelerate business processes, should generate a better competitive position.

The model will be in the form of:

where:

$$
\text { UDIO }=c(1)+c(2) * \text { INFORMA_TROS }
$$

- INFORMA_TROS represents the first variable "the application of information technology" in millions of HRK

- UDIO represents the second variable "achieving a competitive advantage in the banking sector" in percentage.

According to the diagram of the dissipation, it is reasonable to use simple linear regression model. For a better graphical representation $x$ and $y$ axis are increased to such a level that would make regression line visible which will reassure the idea of using linear regression model. 
Figure 1

Diagram of the Dissipation and Regression Line

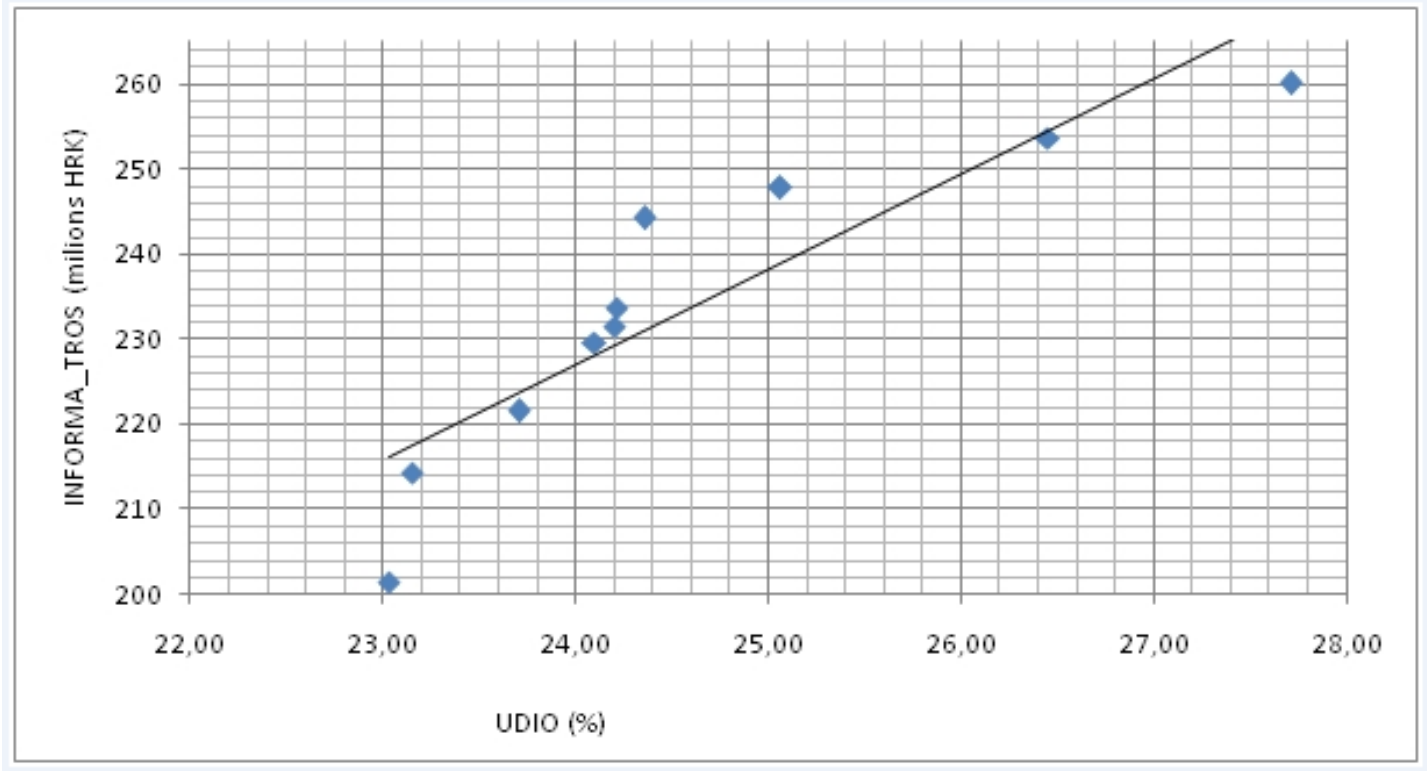

Source: Author's illustration

Table 3

Regression Model Parameter Estimation (Eviews)

\begin{tabular}{|c|c|c|c|c|}
\hline \multicolumn{5}{|c|}{ Dependent Variable: UDIO } \\
\hline \multicolumn{5}{|c|}{ Method: Least Squares } \\
\hline \multicolumn{5}{|l|}{ Sample: 20012010} \\
\hline \multicolumn{5}{|c|}{ Included observations: 10} \\
\hline \multicolumn{5}{|c|}{ UDIO $=C(1)+C(2) * I N F O R M A \_T R O S$} \\
\hline & Coefficient & Std. Error & t-Statistic & Prob. \\
\hline$C(1)$ & 7.793022 & 2.928009 & 2.661543 & 0.0287 \\
\hline$C(2)$ & 0.071895 & 0.012492 & 5.755498 & 0.0004 \\
\hline R-squared & 0.805475 & \multicolumn{2}{|c|}{ Mean dependent var } & 24.59900 \\
\hline Adjusted R-squared & 0.781159 & \multicolumn{2}{|c|}{ S.D. dependent var } & 1.464191 \\
\hline S.E. of regression & 0.684955 & \multicolumn{2}{|c|}{ Akaike info criterion } & 2.257929 \\
\hline Sum squared resid & 3.753305 & \multicolumn{2}{|c|}{ Schwarz criterion } & 2.318446 \\
\hline Log likelihood & -9.289644 & \multicolumn{2}{|c|}{ F-statistic } & 33.12576 \\
\hline Durbin-Watson stat & 1.405014 & \multicolumn{2}{|c|}{ Prob(F-statistic) } & 0.000426 \\
\hline
\end{tabular}

Source: Author

In the specific case regression model is:

$$
\text { UDIO }=7.793022+0.071895^{*} \text { INFORMA_TROS }
$$

The adequacy of the model is tested by the following tests: Jarque-Bera test, skewness and kurtosis parameters (for determining the normality of error terms and the symmetry of the distribution), the t-test (for determining the significance of the dependent variables in the model), the F-test (joint test of significance of variables in the model), the coefficient of determination $\left(R^{2}\right)$, the Durbin-Watson test (for testing the existence of autocorrelation of error terms). White's test (for determining the 
existence of heteroscedasticity), SIC and Akaike criteria (for testing the significance of regressors).

Skewness $=0.487823$ and Kurtosis $=2.577743$ are indicators of individual distribution data normality. The normal distribution skewness should be close to 0 , which in this case can be said that tends to 0 . If the skewness is greater than 0 , data distribution should be more "elongated" in the right, and if it is negative then to the left. Kurtosis of the normal distribution is equal to 3 , and it shows the curvature of the top of the distribution data. In this case, the number tends to 3 , but is slightly smaller, indicating that there is less pointy top.

Figure 2

Results of the Jarque-Bera Test (EViews)

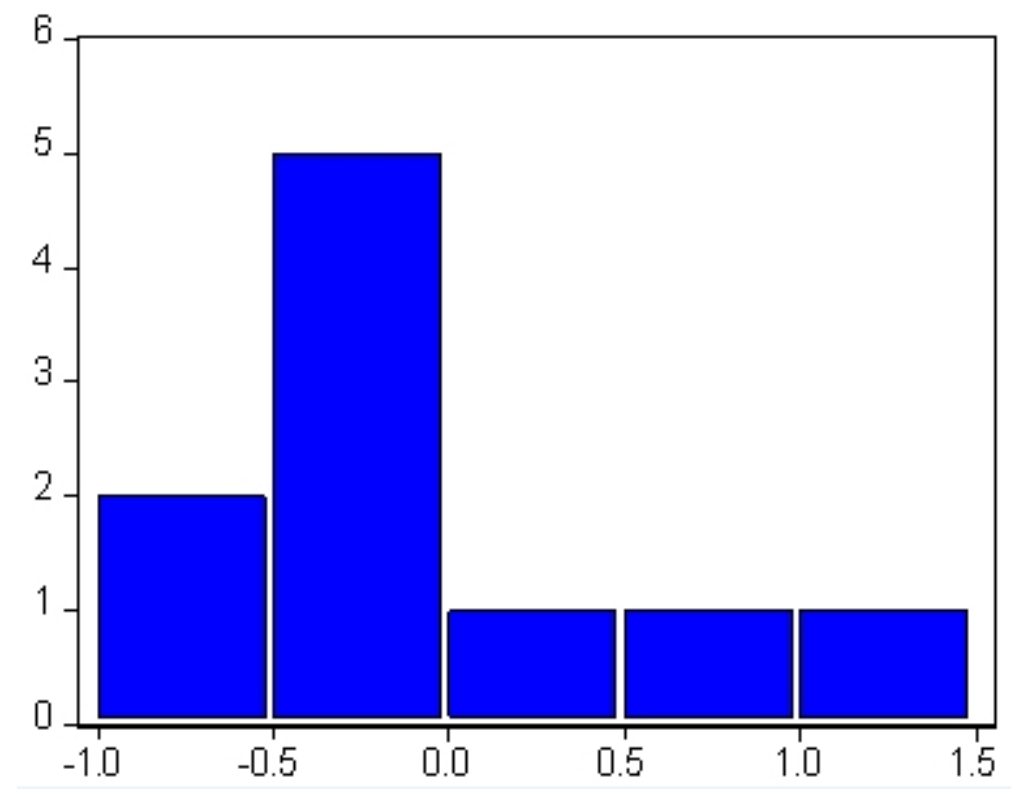

\begin{tabular}{|lr|}
\hline \multicolumn{2}{|l|}{ Series: Residuals } \\
Sample 2001 2010 \\
Observations 10 \\
Mean & $4.99 \mathrm{E}-15$ \\
Median & -0.122618 \\
Maximum & 1.217068 \\
Minimum & -0.988362 \\
Std. Dev. & 0.645782 \\
Skewness & 0.487823 \\
Kurtosis & 2.577743 \\
& \\
Jarque-B era & 0.470912 \\
Probability & 0.790211 \\
\hline
\end{tabular}

Source: Author's illustration

Jarque-Bera test examines the normality of distribution of error terms. In fact, if the assumption of normalityof error terms is not achieved then t-test and F-test are no longer reliable.

Based on the output from the program EViews, p-value in the Jarque-Bera test is equal to 0.790211 , which means that, with a significance level of $5 \%$, error terms are normally distributed. So, the following analysis justified the use of t-test and F-test.

T-test examines the significance of individual independent variables in the model. In the table 3, the p-value for the independent variable INFORMA_TROS is equal to0.0004(very little value) and can therefore be concluded that the independent variable "the application of information technology" is significant in the model.

F-test examines the collective significance of the independent variables in the model. Since the used model contains only one independent variable, in F test decision is the same as the decision in previous t-test. Or, since the Table 3 , shows a pvalue of $\mathrm{F}$ test (Prob (F-statistic)) 0.000426 , conclusion is that, with level of significance $5 \%$, it rejects the assumption that none of the independent variable is not significant in the model. So, the only one independent variable in the model is not insignificant in the model. 
The value of determination coefficient equals to 0.805475 , which means that this model is explained by $80.54 \%$ of the total number of variables, and therefore the model can be considered very good.

The Durbin-Watson test will examine whether is there a problem of autocorrelation of residual deviations of the first order in the model. Since the Durbin-Watson test value is smaller than 2 (equals to 1,405, see Table 3), the problem of the existence of positive autocorrelation of the first order will be examined. With a significance level of $5 \%$ the critical values are $d l=0,879$ and $d u=1,320$. Since it is $d>d u$, in fact, the value of the test value is greater than the upper critical value du, conclusion is that the model has not a problem of autocorrelation of residual deviations of the first order.

Since the Durbin-Watson test indicates autocorrelation of the first order, and no higher, additionally, it is necessary to perform tests which indicate possible higher order auto-correlation.

Table 4

Q- statistics or Correlogram - a Graphical Representation of Autocorrelation (Eviews)

\begin{tabular}{|c|c|c|c|c|c|c|}
\hline \multicolumn{7}{|c|}{$\begin{array}{l}\text { Sample: } 20012010 \\
\text { Included observations: } 10\end{array}$} \\
\hline Autocorrelation & Partial Correlation & & $A C$ & PAC & Q-Stat & Prob \\
\hline$.\left.\quad\right|^{*} . \mid$ & $.\left.\right|^{*} . \mid$ & 1 & 0.093 & 0.093 & 0.1152 & 0.734 \\
\hline${ }^{*}||$. & $.^{* *} \quad . \mid$ & 2 & -0.181 & -0.191 & 0.6069 & 0.738 \\
\hline${ }^{* * *} \mid$ & ${ }^{* * *}$ & 3 & -0.394 & -0.373 & 3.2698 & 0.352 \\
\hline$.^{* *} \quad . \quad \mid$ & ${ }^{* *}$ & 4 & -0.224 & -0.244 & 4.2717 & 0.370 \\
\hline . | |*** & $.\left.\right|^{* *} \cdot \mid$ & 5 & 0.335 & 0.267 & 6.9575 & 0.224 \\
\hline .1 .1 &.$^{* *}||$. & 6 & 0.040 & -0.243 & 7.0055 & 0.320 \\
\hline.$\quad .1$ & $*^{*} \mid$ & 7 & -0.001 & -0.105 & 7.0056 & 0.428 \\
\hline${ }^{*}$ &.$\left.\right|^{*}$. & 8 & -0.092 & 0.081 & 7.5123 & 0.483 \\
\hline
\end{tabular}

Source: Author

As can be seen from the graph, no autocorrelation coefficient value goes beyond value that would indicate autocorrelation of the first or higher order. Another indication is the last column (Prob) or $\mathrm{p}$ - value which is high for all the values in rows. For all the significance levels 1, 5 or $10 \%$ the $p$ value is greater, and this tells us that no autocorrelation of a higher order exists (Table 4).

To test the existence of the problem of heteroskedasticity in the model White's test will be used.

Table 5

White's Test for Heteroskedasticity (Eviews)

\begin{tabular}{|c|c|c|c|}
\hline \multicolumn{4}{|c|}{ White Heteroskedasticity Test: } \\
\hline F-statistic & 4.964889 & \multirow{2}{*}{$\begin{array}{l}\text { Probability } \\
\text { Probability }\end{array}$} & 0.045453 \\
\hline $\begin{array}{l}\text { Obs*R-squared } \\
\text { Test Equation: }\end{array}$ & 5.865273 & & 0.053256 \\
\hline Variable & Coefficient & †-Statistic & Prob. \\
\hline C & 46.10123 & 2.386140 & 0.0484 \\
\hline INFORMA_TROS & -0.410126 & -2.449176 & 0.0442 \\
\hline INFORMA_TROS^2 & 0.000913 & 2.525509 & 0.0395 \\
\hline R-squared & 0.586527 & Mean dependent var & 0.375331 \\
\hline Adjusted R-squared & 0.468392 & S.D. dependent var & 0.496948 \\
\hline S.E. of regression & 0.362332 & Akaike info criterion & 1.050812 \\
\hline Sum squared resid & 0.918990 & Schwarz criterion & 1.141588 \\
\hline Log likelihood & -2.254060 & F-statistic & 4.964889 \\
\hline Durbin-Watson stat & 2.625363 & Prob(F-statistic) & 0.045453 \\
\hline
\end{tabular}

Source: Author 
White's Test results are shown in Table 5 and, with the level of significance of $5 \%$, they don't reject the assumption of homoscedasticity or stability of invariance ( $p$-value associated with the Obs * $R 2$ is equal to 0.053256$)$.

Table 6

The Correlation Matrix (Eviews)

\begin{tabular}{lll}
\hline & INFORMA_TROS & UDIO \\
\hline INFORMA_TROS & 1.000 .000 & 0.897482 \\
UDIO & 0.897482 & 1.000 .000 \\
\hline
\end{tabular}

Source: Author

The correlation matrix shows that the coefficient of linear correlation between the variables: "the application of information technology" and "achieving a competitive advantage in the banking sector" is equal to 0.897482 which says that between these two variables there is a strong positive linear relationship (Table 6).

\section{Discussion}

Information technology has reached a stage of development in which, we can say, it is no longer the limiting factor in the implementation of a solution to a problem. All that men can think of, IT can support and implement. But how to justify investment in IT? Is it worth it to invest, and to what extent? This work establishes a clear link between investment in IT and size of market share in the banking sector, as an answer to these questions.

The paper is based on an analysis of IT investments and the market share of the largest Croatian bank between 2001 and 2010 as a direct consequence of this methodology, the study encountered a number of limitations, which need to be considered. The data we used are related to the time before the start of the economic crisis, when investments were not hit by cost-cutting and are guided exclusively by assessment of the technical staff. So, effects of economic crisis are avoided. Also, study is limited to Croatian market, and it would be interesting to confirm these findings in another market, or maybe even industry.

\section{Conclusion}

So, we can conclude that the application of information technology plays an important role in achieving a competitive advantage in the banking sector.

The banking sector, independently in Croatia and in the world, is leading economic sector for investment in IT. The vast majority of entities concerned: managers, employees, customers, intuitive conclude that information technology has a positive effect on the competitive advantage. This intuitive thinking fits into the scientific framework and its results can be used as an argument in the development planning and IT investments in banks.

The suggested direction for further research is cost-effectiveness and optimal investment in IT, aimed at solving a particular problem. The solution is not uncontrolled investment in IT and e-business development. Also, it would be useful to run case studiesto check whether the initial market share has an impact on the linear relationship between variables in this research. 


\section{References}

1. Alawneh, A., Hattab, E. (2009), "An Empirical Study of Sources Affecting E-Business Value Creation in Jordanian Banking Services Sector", International Arab Journal of eTechnology, Vol. 1 No. 2, pp. 1-8.

2. Auta, E. M. (2010), "E-banking in developing economy: empirical evidence from Nigeria", Journal of applied quantitative methods, Vol. 5 No. 2, pp. 212-222.

3. Coltman, T. (2007), "Can Superior CRM Capabilities Improve Performance in Banking", Journal of Financial Services Marketing, Vol. 12 No. 2, pp. 102-114.

4. Devaraj, S., Kohli, R. (2002), "The IT Payoff: Measuring the business value of information technology investments". New Jersey: Prentice Hall.

5. Hrvatska narodna banka (Croatian national bank) (2011), "Bilteni" ("Newsletters"), Hrvatska narodna banka. Available at: http://www.hnb.hr/supervizija/hsupervizija.htm (accessed June $5^{\text {th }}$ 2015).

6. Joseph, M. et al. (2005), "An exploratory study on the use of banking technology in the UK: A ranking of importance of selected technology on consumer perception of service delivery performance", International Journal of Bank, Vol. 23 No. 5. pp. 397-413.

7. Malhotra, P., Singh, B. (2009), "The Impact of Internet Banking on Bank Performance and Risk: The Indian Experience", Eurasian Journal of Business and Economics, Vol. 2 No. 4, pp. 43-62.

8. Nel, F. L. (2008), "Information Technology Investment Evaluation and Measurement (ITIEM): A case study and action research of the dimensions and measures of IT-business-value in Financial Institutions", paper ID 15983, Queensland University of Technology, (accessed December 3 rd 2008).

9. Ryan, R., Raducha-Grace, T. (2010), "The Business of IT: How to improve service and lower costs". Indianapolis: IBM Press.

10. Zagrebačka banka (2011), "'Godišnja izvješća 2001-2010" ("Annual Reports"), available at:

http://www.zaba.hr/home/wps/wcm/connect/zaba_hr/zabapublic/odnosi_s_investitori ma/financijski+izvjestaji (accessed June $5^{\text {th }} 2015$ )

\section{About the author}

Denis Hrestak works as a member of the Board of the leading Croatian IT company APIS IT. He began his career in the automotive industry in the company AD Plastik, and then fifteen years he spent at various jobs in the department of information technology in Zagrebacka banka Itd. He graduated from the Faculty of Electrical Engineering and Computing, University of Zagreb, Master's degree at the Faculty of Economics, University of Zagreb, and is currently writing his doctoral thesis at the Faculty of Commercial and Business Knowledge in Celje, Slovenia. Author can be contacted at denis.hrestak@gmail.com 